\author{
P. R. Sharps \\ EMCORE Photovoltaics \\ 10420 Research Road SE \\ Albuquerque, NM 87112 \\ Phone: 505/332-5022 \\ Fax: 505/332-5038 \\ Paul_Sharps@emcore.com \\ Category 4B \\ Oral
}

\title{
AlGaAs/InGaAlP Tunnel Junctions for Multijunction Solar Cells
}

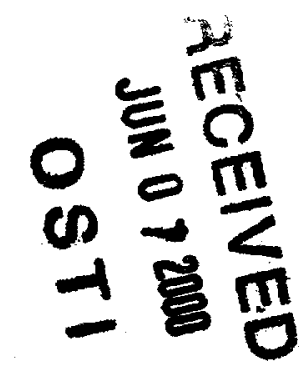

\author{
P. R. Sharps, N. Y. Li, J. S. Hills, and H. Hou \\ EMCORE Photovoltaics \\ 10420 Research Road SE \\ Albuquerque, NM 87112 \\ P. C. Chang and A. Baca \\ Sandia National Laboratory \\ Advanced Semiconductor Technology \\ P.O. Box 5800 \\ Albuquerque, NM 87185-0603
}

Optimization of GaInP $2 / \mathrm{GaAs}$ dual and $\mathrm{GaInP}_{2} / \mathrm{GaAs} / \mathrm{Ge}$ triple junction cells, and development of future generation monolithic multi-junction cells will involve the development of suitable high bandgap tunnel junctions. There are three criteria that a tunnel junction must meet. First, the resistance of the junction must be kept low enough so that the series resistance of the overall device is not increased. For AM0, 1 sun operation, the tunnel junction resistance should be below $5 \times 10^{-2} \Omega-\mathrm{cm}$. Secondly, the peak current density for the tunnel junction must also be larger than the $\mathrm{J}_{\mathrm{sc}}$ of the cell so that the tunnel junction I-V curve does not have a deleterious effect on the I-V curve of the multi-junction device. Finally, the tunnel junction must be optically transparent, i.e., there must be a minimum of optical absorption of photons that will be collected by the underlying subcells.

We have looked at four "high" bandgap tunnel junctions, $\mathrm{Al}_{0.4} \mathrm{Ga}_{0.6} \mathrm{As}: \mathrm{C} / \mathrm{In}_{0.5} \mathrm{Ga}_{0.5} \mathrm{P}: \mathrm{Si}$, $\quad \mathrm{Al}_{0.4} \mathrm{Ga}_{0.6} \mathrm{As}_{\mathrm{S}} \mathrm{C} / \mathrm{In}_{0.5} \mathrm{Ga}_{0.4} \mathrm{Al}_{0.1} \mathrm{P}: \mathrm{Te}$, $\mathrm{Al}_{0.9} \mathrm{Ga}_{0.1} \mathrm{As}: \mathrm{C} \mathrm{In}_{0.5} \mathrm{Ga}_{0.3} \mathrm{Al}_{0.2} \mathrm{P}: \mathrm{Si}$, and $\mathrm{Al}_{0.9} \mathrm{Ga}_{0.1} \mathrm{As}: \mathrm{C} / \mathrm{In}_{0.5} \mathrm{Ga}_{0.3} \mathrm{Al}_{0.2} \mathrm{P}: \mathrm{Te}$. The bandgap of $\mathrm{Al}_{0.9} \mathrm{Ga}_{0.1} \mathrm{As}$ and $\mathrm{Al}_{0.4} \mathrm{Ga}_{0.6} \mathrm{As}$ are $2.1 \mathrm{eV}$ and $1.9 \mathrm{eV}$, respectively, while the bandgap of $\mathrm{In}_{0.5} \mathrm{Ga}_{0.3} \mathrm{Al}_{0.2} \mathrm{P}$ and $\mathrm{In}_{0.5} \mathrm{Ga}_{0.4} \mathrm{Al}_{0.1} \mathrm{P}$ are $2.1 \mathrm{eV}$ and $2.0 \mathrm{eV}$, respectively. Each active layer of the tunnel junction is $250 \AA$ thick, sandwiched by GaAs layers. All of the tunnel junctions were grown by metal-organic chemical vapor deposition (MOCVD), the growth method of choice for commercial production of III-V space solar cells. All of the devices have the p-on-n structure, and were processed as $100 \mu \mathrm{m} \times 100 \mu \mathrm{m}$ diodes. The maximum electron density achieved for Si doping of both compositions of InGaAlP is $5 \mathrm{x}$ $10^{18} \mathrm{~cm}^{-3}$. With Te, an electron carrier density of $1.5 \times 10^{19} \mathrm{~cm}^{-3}$ is achievable. Both

Sandia is a multiprogram laboratory operated by Sandia Corporation, a Lockheed Martin Company, for the United States Department of Energy under Contract DE-AC04-94AL85000. 


\section{DISCLAIMER}

This report was prepared as an account of work sponsored by an agency of the United States Government. Neither the United States Government nor any agency thereof, nor any of their employees, make any warranty, express or implied, or assumes any legal liability or responsibility for the accuracy, completeness, or usefulness of any information, apparatus, product, or process disclosed, or represents that its use would not infringe privately owned rights. Reference herein to any specific commercial product, process, or service by trade name, trademark, manufacturer, or otherwise does not necessarily constitute or imply its endorsement, recommendation, or favoring by the United States Government or any agency thereof. The views and opinions of authors expressed herein do not necessarily state or reflect those of the United States Government or any agency thereof. 


\section{DISCLAIMER}

Portions of this document may be illegible in electronic image products. Images are produced from the best available original document. 
compositions of $\mathrm{AlGaAs}$ are doped with $\mathrm{C}$, with a maximum hole density of $1.5 \times 10^{19}$ $\mathrm{cm}^{-3}$ being attained.

The I-V curves for the different tunnel junctions are shown in the Figures 1 through 4, along with the peak current and series resistance for each structure. Only the $\mathrm{Al}_{0.9} \mathrm{Ga}_{0.1} \mathrm{As}: \mathrm{C} / \mathrm{In}_{0.5} \mathrm{Ga}_{0.3} \mathrm{Al}_{0.2} \mathrm{P}: \mathrm{Te}$ tunnel junction meets the criteria mentioned previously, with $J_{p}$ being $1,500 \mathrm{~mA} \mathrm{~cm}^{2}$, and $R_{s}$ being $2.5 \times 10^{-2} \Omega-\mathrm{cm}^{2}$. While it is possible to degenerately dope $\mathrm{In}_{0.5} \mathrm{Ga}_{0.5} \mathrm{P}$ with $\mathrm{Si}$, the level is not high enough to reduce the series resistance to the values needed for a multijunction device. With $\mathrm{In}_{0.5} \mathrm{Ga}_{0.3} \mathrm{Al}_{0.2} \mathrm{P}$, however, degeneracy cannot be achieved with $\mathrm{Si}$ doping, as can be seen from Fig. 3. Compensation occurs before degeneracy is reached, with increased amounts of $\mathrm{Si}$ above a certain point reducing the n-type carrier density.

Because of concern about a Te memory effect, an iteration of the $\mathrm{In}_{0.5} \mathrm{Ga}_{0.3} \mathrm{Al}_{0.2} \mathrm{P}: \mathrm{Te} / \mathrm{Al}_{0.9} \mathrm{Ga}_{0.1} \mathrm{As}: \mathrm{C}$ tunnel junction was grown with reduced amounts of Te. Unfortunately, the series resistance of the junction is increased to an unacceptable level. The precise growth conditions have a significant effect on the final device results.

A SIMS analysis was done on the sample shown in Fig. 4, to determine how abrupt the doping profiles are, and to see any Te memory effect. The results indicate that within $0.1 \mu \mathrm{m}$ the Te doping level drops to the background level. The Te memory effect is minimal, and should have no effect on a multijunction device that would use the $\mathrm{In}_{0.5} \mathrm{Ga}_{0.3} \mathrm{Al}_{0.2} \mathrm{P}: \mathrm{Te} / \mathrm{Al}_{0.9} \mathrm{Ga}_{0.1}$ As: $\mathrm{C}$ tunnel diode.

To our knowledge, the $\mathrm{Al}_{0.9} \mathrm{Ga}_{0.1} \mathrm{As}: \mathrm{C} / \mathrm{In}_{0.5} \mathrm{Ga}_{0.3} \mathrm{Al}_{0.2} \mathrm{P}: \mathrm{Te}$ tunnel junction is the highest bandgap tunnel junction made to date. The tunnel junction has the necessary optical and electrical properties such that it could be used in a AM0, 1-sun monolithic multijunction solar cell.

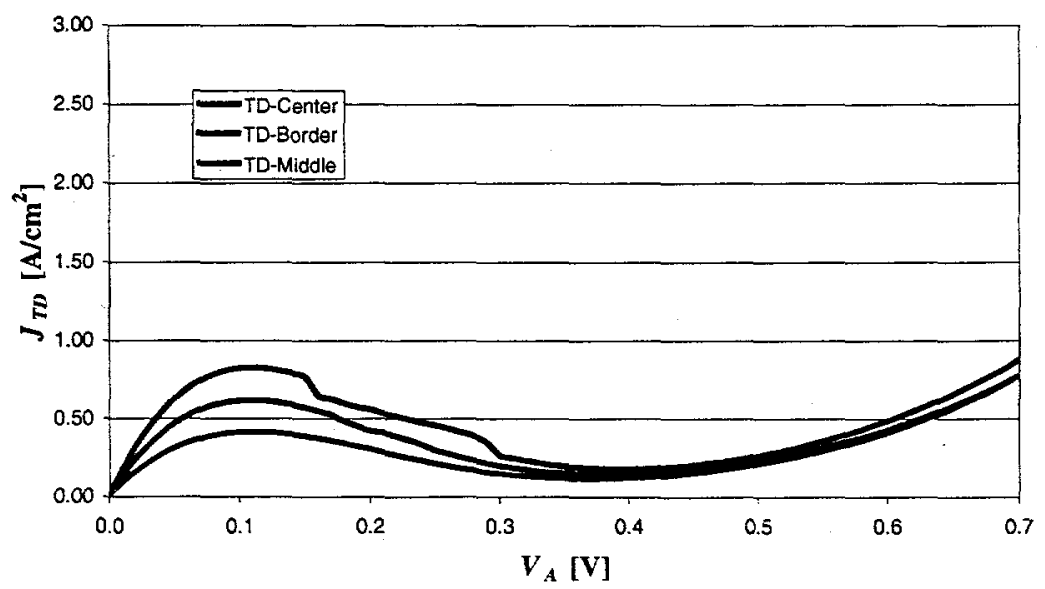

Figure 1. I-V curve for the $\mathrm{In}_{0.5} \mathrm{Ga}_{0.5} \mathrm{P}: \mathrm{Si} / \mathrm{Al}_{0.4} \mathrm{Ga}_{0.6} \mathrm{As}: \mathrm{C}$ tunnel diode. The $\mathrm{J}_{\mathrm{p}}$ is 600 $\mathrm{mA} / \mathrm{cm}^{2}$, and the $R_{s}$ is $7.5 \times 10^{-2} \Omega-\mathrm{cm}^{2}$. 


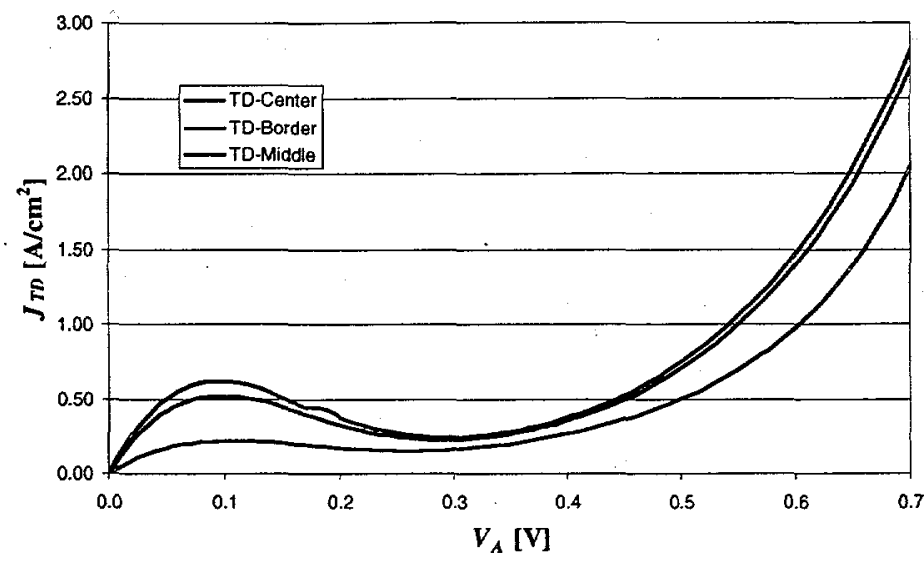

Figure 2. I-V curve for the $\operatorname{In}_{0.5} \mathrm{Ga}_{0.4} \mathrm{Al}_{0.1} \mathrm{P}: \mathrm{Te} / \mathrm{Al}_{0.4} \mathrm{Ga}_{0.6} \mathrm{As}: \mathrm{C}$ tunnel diode. The $\mathrm{J}_{\mathrm{p}}$ is $500 \mathrm{~mA} / \mathrm{cm}^{2}$, and the $R_{\mathrm{s}}$ is $7.5 \times 10^{-2} \Omega-\mathrm{cm}^{2}$.

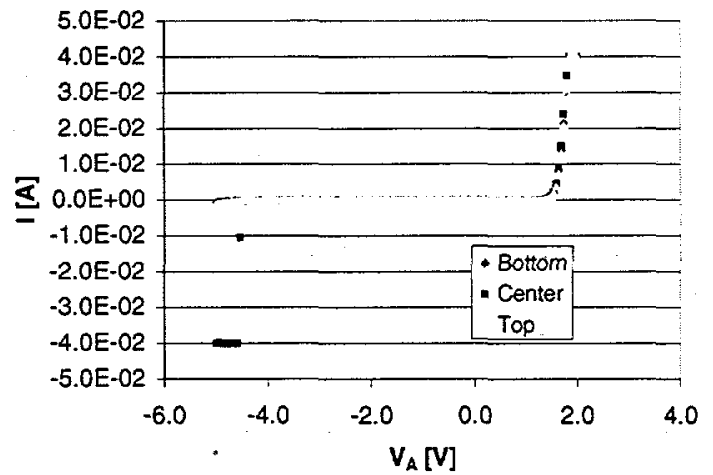

Figure 3. I-V curve for the $\operatorname{In}_{0.5} \mathrm{Ga}_{0.3} \mathrm{Al}_{0.2} \mathrm{P}: \mathrm{Si} / \mathrm{Al}_{0.9} \mathrm{Ga}_{0.1} \mathrm{As}: \mathrm{C}$ junction. No tunneling action is seen because the $\operatorname{In}_{0.5} \mathrm{Ga}_{0.3} \mathrm{Al}_{0.2} \mathrm{P}: \mathrm{Si}$ is not degenerate.

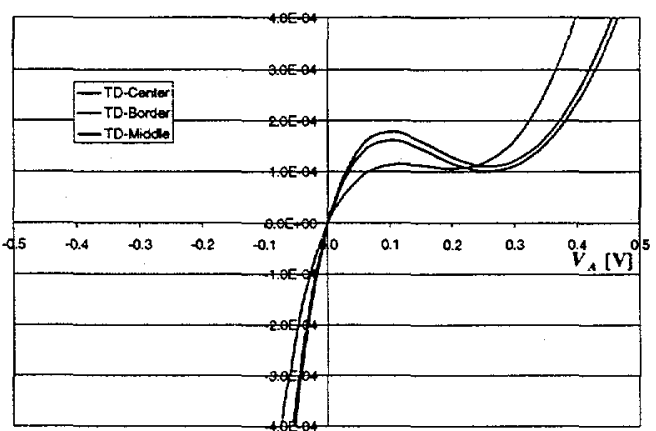

Figure 4. I-V curve for the $\mathrm{In}_{0.5} \mathrm{Ga}_{0.3} \mathrm{Al}_{0.2} \mathrm{P}: \mathrm{Te} / \mathrm{Al}_{0.9} \mathrm{Ga}_{0.1} \mathrm{As}: \mathrm{C}$ tunnel diode. The $\mathrm{J}_{\mathrm{p}}$ is $1,500 \mathrm{~mA} / \mathrm{cm}^{2}$, and the $R_{s}$ is $2.5 \times 10^{-2} \Omega-\mathrm{cm}^{2}$. 